\title{
Serum allergen-specific IGE to common aeroallergens among allergic rhinitis patients in Egypt
}

\author{
Hossam Moustafa Elkady ${ }^{1^{*}}$ (D) and Ahmed Atef $^{2}$
}

\begin{abstract}
Background: Allergic rhinitis is the most prevalent allergic disease, and the prevalence and sensitization patterns differ among countries. Identifying the most common inhalant allergen in each region plays a key role in the diagnosis and management of allergic rhinitis. There are no data available about the most prevalent aeroallergen among allergic rhinitis patients in Egypt. The aim of this study is to evaluate the prevalence of positive serum allergen-specific IGE to common inhalant allergens among allergic rhinitis patients in Egypt. A cross-sectional study was conducted on 354 allergic rhinitis patients, serum allergen-specific IGE was measured by using the Immuno CAP system to 16 common regional aeroallergens including (pollens, mite, molds, animal dander, and cockroach).

Results: The overall rate of sensitization to any allergen was $74.6 \%$. Dermatophagoides pteronyssinus, birch pollens, and Dermatophagoides farina were the most prevalent allergens $(29.7 \%, 23.7 \%$, and $18.6 \%)$, respectively.

Cladosporuim molds were the least prevalent individual allergens (1.7\%).

Conclusion: Our data suggest that Dermatophagoides pteronyssinus and birch pollens were the predominant allergen sources among allergic rhinitis patient in Egypt.
\end{abstract}

Keywords: Aeroallergen, Allergic rhinitis, Serum allergen-specific IGE

\section{Background}

Allergic rhinitis (AR) is induced by a reaction mediated by immunoglobulin $\mathrm{E}$ in allergen sensitized patient and is characterized by recurrent sneezing, runny nose, nasal congestion, and itchy nose, which most often associated with ocular itching, redness, and/or lacrimation in 60 $70 \%$ of cases [1].

The prevalence of AR was reported between 10 and $30 \%$ of adults and $40 \%$ of children [2].

The most common cause of AR is hypersensitivity to inhalant allergens. The type and quantity of inhalant allergens vary depending on the geographical variation, seasonal and climatic changes, and location [3]. Identification of the most common inhalant allergen in each

\footnotetext{
* Correspondence: hossamelkady86@ymail.com

${ }^{1}$ Department of Internal Medicine, Allergy and Clinical Immunology, Faculty

of Medicine, Ain Shams University, Cairo, Egypt

Full list of author information is available at the end of the article
}

region contributes to the diagnosis and management of allergic rhinitis. Numerous studies have shown that the distribution and type of inhalant allergens vary varies between countries and from region to region [4].

The results of serum allergen-specific IgE are closely related to the results of skin prick tests and nasal challenge test. Allergen-specific IgE tests are very specific and sensitive. One of their benefits is that medication and skin lesions do not affect the results [5].

Although the prevalence of AR is very high in Egypt, no data are available on the most common aeroallergens, so this study aims to assess the prevalence of positive serumspecific IgE to various common aeroallergens among patients with allergic rhinitis in Egypt, to develop an effective strategy for the prevention and management of allergic rhinitis. The aim of this study was to evaluate the prevalence of positive serum-specific IGE to common inhalant allergens among allergic rhinitis patients in Egypt.

\section{Springer Open}

(ㅇ The Author(s). 2021 Open Access This article is licensed under a Creative Commons Attribution 4.0 International License, which permits use, sharing, adaptation, distribution and reproduction in any medium or format, as long as you give appropriate credit to the original author(s) and the source, provide a link to the Creative Commons licence, and indicate if changes were made. The images or other third party material in this article are included in the article's Creative Commons licence, unless indicated otherwise in a credit line to the material. If material is not included in the article's Creative Commons licence and your intended use is not permitted by statutory regulation or exceeds the permitted use, you will need to obtain permission directly from the copyright holder. To view a copy of this licence, visit http://creativecommons.org/licenses/by/4.0/. 


\section{Methods}

\section{Study population and design}

A cross-sectional study was performed on 354 patients with symptoms of allergic rhinitis, who were referred to outpatient clinic of Allergy and Clinical Immunology, between January and December 2019, in accordance with the ethical standards of faculty of medicine ethical committee.

Included criteria were (1) diagnosis of allergic rhinitis as defined by a complaint of any combination of the following symptoms: itchy nose, sneezing, runny, or blocked nose without a cold or flu in over the past 12 months.

(2) Patients with moderate to severe allergic rhinitis.

(3) Non-allergic rhinitis patients and smoker were excluded from this study.

(3) Negative history of specific immunotherapy.

Patient demographics were obtained from history.

\section{Specific IGE}

The serum allergen sIgE for 16 common aeroallergen (dermatophagoides 3arina, dermatophagoides pteronyssinus, alternaria 3arina3te, Aspergillus niger, aspergillus fumigatus, candida albicans, cladosporim herbarum, penicillium notatum, mix grasses pollens, birch, ragweed, cat, dog, feather mixture, cockroach, and horse epithelium) was measured in all patients by using the ImmunoCAP system according to the manufacturer's instruction (Pharmacia, Uppsala, Sweden).

The CAP classification system divides results into seven categories from 0 to 6 . Additional classes are scored as follows: $<0.35 \mathrm{kU} / \mathrm{L}$ class $0 ; 0.35-0.70 \mathrm{kU} / \mathrm{L}$, class $1 ; 0.71-3.50 \mathrm{kU} / \mathrm{L}$ class $2 ; 3.51-7.50 \mathrm{kU} / \mathrm{L}$, class 3; $7.60-17.50 \mathrm{kU} / \mathrm{L}$ class $4 ; 17.60-50.00 \mathrm{kU} / \mathrm{L}$ class $5 ;>50$ $\mathrm{kU} / \mathrm{L}$ class 6 . The units reported by CAP are in accordance with the defined WHO serum standard IRP 75/ 520. For the present analyses, patients were classified as sensitive to the allergens if the serum $\operatorname{IgE}$ level was $\geq$ $0.35 \mathrm{kU} / \mathrm{L}$.

\section{Statistical analysis}

Data were gathered, revised, coded, and entered into version 23 of the Statistical Package for Social Sciences (IBM SPSS). IBM Corp. Released 2015. IBM SPSS Statistics for Windows, Version 23.0. Armonk, NY: IBM Corp. The quantitative data with parametric distribution while with non-parametric were presented as median with inter- range (IQR) quartile. Qualitative variables were also displayed as numbers and percentages.

\section{Results}

Three hundred and fifty-four patients were evaluated for serum-specific IGE against 16 aeroallergens. There were 207 (58.5\%) females and 147 (41.5\%) males evaluated for serum-specific IGE against common aeroallergens. The mean $( \pm \mathrm{SD})$ age of the patients was $34.82 \pm 16.63)$ with range from 10 to 85 . Concomitant asthma was found in $24.6 \%$, and allergic conjunctivitis in $13.6 \% \%$. Demographic and clinical characterization of the patients is presented in (Table 1).

Overall rating of sensitization to any allergen was observed in $74.6 \%$ of the patients, with $25.4 \%$ of the patients showed negative serum-specific IGE to any of the tested allergens.

Moreover, Dermatophagoides pteronyssinus, birch tree, Dermatophagoides 4arina, and Alternaria alternate were the most prevalent allergens $(29.7 \%, 23.7 \%, 18.6 \%$, $16.1 \%)$, respectively, among the patients with allergic rhinitis (Fig. 1). Among the study sample of patients, Dermatophagoides pteronyssinus was the most common allergen (29.7\%), Dermatophagoides farina (18.7\%), animal dander (cat hair 11\% and dog epithelia 10.2\%, horse epithelium $1.7 \%$ ), feather mixture $3.4 \%$, coacroach $6.8 \%$. Among molds, Alternaria alternate was the most prevalent allergen $16.1 \%$, followed by Aspergillus fumigatus 13.6\%, Candida albicans 12.7\%, Aspergillus niger 5.1\%, Penicillium notatum $3.4 \%$, and Cladosporium was the least prevalent mold allergen 1.7\%). Among outdoor allergens, birch tree pollen (23.7\%) made the most prevalent allergen followed by mix grasses pollen (13.6\%), sun flower seed 9.3\%) (Table 2). The results have shown that $74.6 \%$ of the patients were poly-sensitized to two or more allergens, $8.5 \%$ of the patients were sensitized to more than five allergens (Fig. 2).

\section{Discussion}

Several studies have been conducted to evaluate effectiveness of specific IgE tests in the diagnosis of allergy. Results that have been reported from multi-center studies showed sensitivity in a range of 84 to $95 \%$ and specificity ranging from 85 to $94 \%$ [6].

Diagnosis of allergic rhinitis is based on a synergy between allergic symptoms and diagnostic tests. In vitro

Table 1 Demographic and clinical characterization of the patients

\begin{tabular}{lll}
\hline & & Total no. = 354 \\
\hline Sex & Males & $147(41.5 \%)$ \\
Age & Females & $207(58.5 \%)$ \\
& Mean \pm SD & $34.82 \pm 16.63$ \\
Associated allergic conjunctivitis & Range & $10-85$ \\
& Yes & $306(86.4 \%)$ \\
Associated bronchial asthma (BA) & No & $48(13.6 \%)$ \\
& Yes & $87(24.67 \%)$ \\
\hline
\end{tabular}




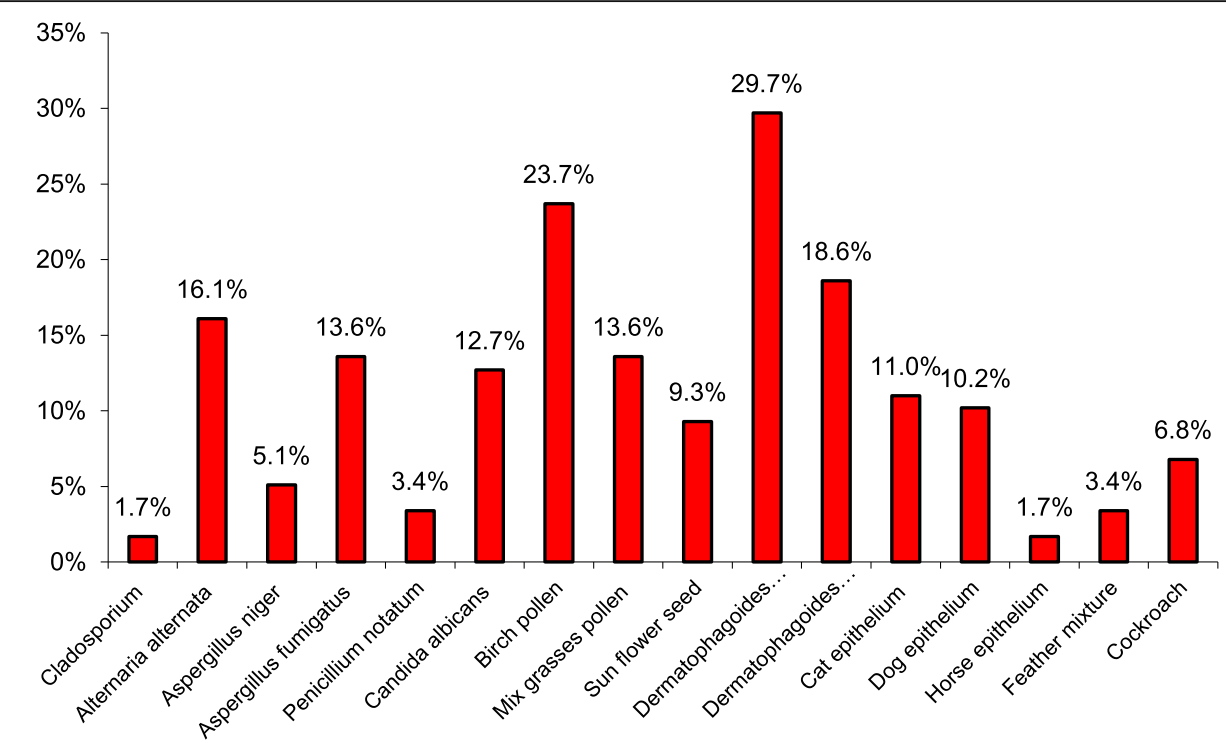

Fig. 1 Prevalence of positive-specific IGE to common aeroallergen among allergic rhinitis patients

analysis and in vivo methods used to detect IgE (cellbound or free) [7].

Serum IgE is generally considered to be specific biomarker for the allergic reaction, as the allergic disorders are characterized by an inflammatory response mediated by IgE. Measuring of IGE is a popular method for diagnosing allergies [8].

The present study aimed to estimates of the prevalence of inhalant allergens to provide valuable information to develop effective strategies for the prevention and treatment of allergic rhinitis. The author conducted an epidemiologic survey of AR and examined the sensitization rates against common aeroallergens by measuring the serum-specific IgE of 354 patients aged between 10 and 85 years in an Egyptian population between January and December 2019.

The findings of this study have revealed a high sensitization rate to any allergen (74.6\%), which is almost

Table 2 Prevalence of positive-specific IGE to common aeroallergen among allergic rhinitis patients

\begin{tabular}{|c|c|c|c|c|}
\hline & Median/mean ${ }^{a}$ & Range & Negative & Positive \\
\hline Cladosporium $^{a}$ & $4.03 \pm 0.74$ & $3.5-4.55$ & $348(98.3 \%)$ & $6(1.7 \%)$ \\
\hline Alternaria alternata & $2.5(1.3-15.8)$ & $0.36-100$ & $297(83.9 \%)$ & $57(16.1 \%)$ \\
\hline Aspergillus niger & $1.1(0.53-1.8)$ & $0.35-3.9$ & $336(94.9 \%)$ & $18(5.1 \%)$ \\
\hline Aspergillus fumigatus & $0.58(0.4-2.2)$ & $0.35-12.6$ & $306(86.4 \%)$ & $48(13.6 \%)$ \\
\hline Penicillium notatum & $0.36(0.35-0.65)$ & $0.35-0.93$ & $342(96.6 \%)$ & $12(3.4 \%)$ \\
\hline Candida albicans & $0.61(0.37-0.85)$ & $0.35-39$ & $309(87.3 \%)$ & $45(12.7 \%)$ \\
\hline Birch pollen & $0.52(0.36-2)$ & $0.35-11.2$ & $270(76.3 \%)$ & $84(23.7 \%)$ \\
\hline Mix grasses pollen & $1.31(0.56-6.05)$ & $0.35-22.2$ & $306(86.4 \%)$ & $48(13.6 \%)$ \\
\hline Sun flower seed & $1(0.37-3.8)$ & $0.35-16.6$ & $321(90.7 \%)$ & $33(9.3 \%)$ \\
\hline Mite $\mathrm{p}$ (Dermatophagoides pteronyssinus) & $1.6(0.59-5.8)$ & $0.35-31$ & $249(70.3 \%)$ & $105(29.7 \%)$ \\
\hline Mite f (Dermatophagoides farinae) & $2.75(0.53-6.7)$ & $0.34-75$ & $288(81.4 \%)$ & $66(18.6 \%)$ \\
\hline Cat epithelium & $14.5(7.2-100)$ & $0.53-100$ & $315(89.0 \%)$ & $39(11.0 \%)$ \\
\hline Dog epithelium & $0.66(0.37-1.35)$ & $0.35-30$ & $318(89.8 \%)$ & $36(10.2 \%)$ \\
\hline Horse epithelium & $3.99(0.5-7.47)$ & $0.5-7.47$ & $348(98.3 \%)$ & $6(1.7 \%)$ \\
\hline Feather mixture & $1.45(0.83-2.05)$ & $0.35-2.5$ & $342(96.6 \%)$ & $12(3.4 \%)$ \\
\hline Cockroach & $2(1.65-5.25)$ & $0.66-5.8$ & $330(93.2 \%)$ & $24(6.8 \%)$ \\
\hline
\end{tabular}

All data were presented as median with IQR with numbers and percentages

${ }^{a}$ Data were presented as mean \pm SD with number and percentages 


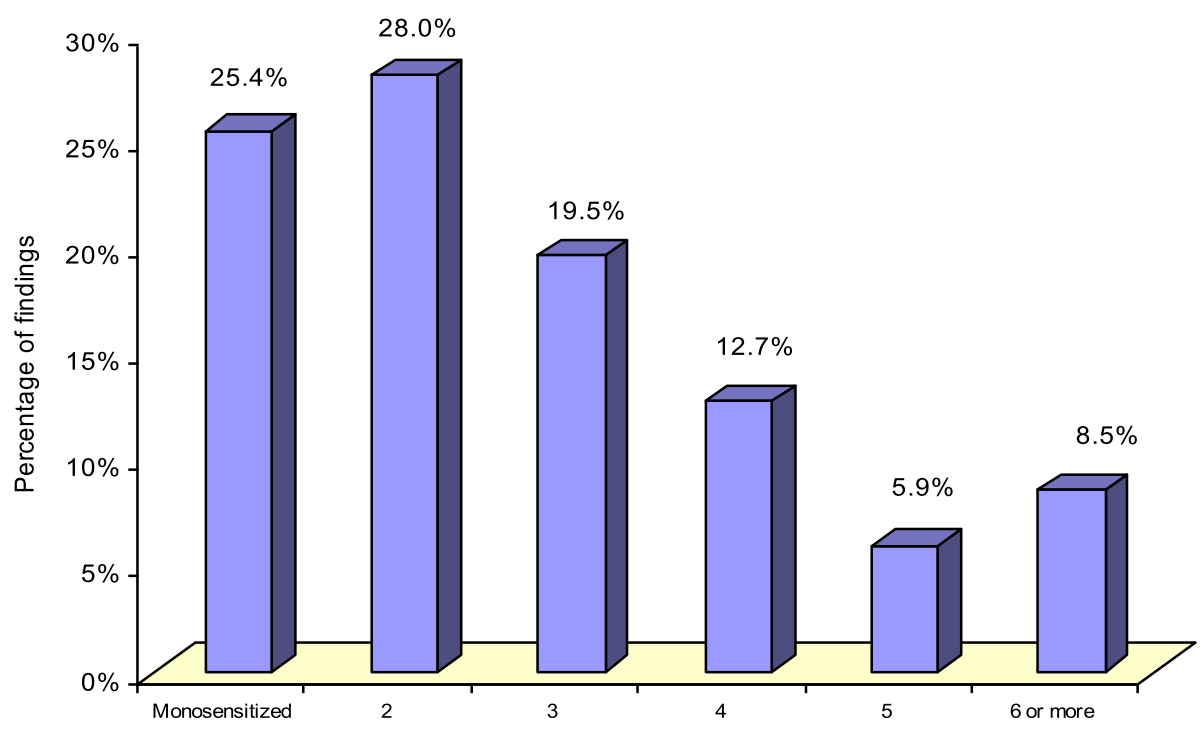

Fig. 2 Percentage of patients by number of positive serum-specific IGE to allergens

similar to the previous study in japan [9]. The results have shown that $74.6 \%$ of the patients were polysensitized to two or more allergens. Multi-allergen sensitization was caused by numerous factors including, hereditary, environmental factors, and crosssensitization between allergens sharing common allergenic epitopes.

House dust mite was the most common allergens with Dermatophagoides pteronyssinus $(29.7 \%)$ followed by Dermatophagoides farina (18.6\%). Other studies in humid regions like Thailand [10] and in hot and dry regions like Kuwait [11] also showed a higher rate of sensitization to house dust mites. However, the climate of Egypt is dry and moderate. The possible reason of increased prevalence of mite's allergy could be increased use of air conditioners that make the environment favorable for mites. Another possible explanation could be increased humidity in coastal cities of Egypt that make them favorable for dust mite growth.

In our study, serum allergen-specific IGE in patients with allergic rhinitis reported a high incidence of pollen allergen and the most prevalent was found to be birch pollen, because Birch pollen allergens induce large and complex patterns of IgE cross-reactivity [12]. These results are consistent with a local study conducted with skin prick test on 135 patients having AR in Egypt [13].

In this study, the rate of sensitization to cat allergen was $11 \%$ and sensitization rate to dog allergen was $10.2 \%$. These results were in contrast to studies done in countries like the USA and Sweden refer to the fact that in these countries more than $60 \%$ of the households keep pets and more than 161 million of these pets were dogs and cats [14], as only a few families in Egypt keep cats or dogs as pets in their homes.
Regarding molds, the most common fungal allergen was found to be Alternaria. Alternate (16.1\%) followed by Aspergulluis fumigatus (13.6) which nearly similar to studies in the USA [15] and Sudan [16]. Least prevalent mold was found to be cladosporuim with $1.7 \%$ similar to study in the Kingdom of Saudi Arabia [16].

About $25.4 \%$ of the patients showed undetectablespecific IGE in serum against common aeroallergen. The explanation for these negative results could be due to the lower sensitivity serum-specific IGE than SPT [17], and the fact that patients were allergic to particular allergens that were not tested in the study.

Since we have not yet found any studies conducted on this subject in our region, we report here for the first time, the most common aeroallergens detected by serumspecific IGE between allergic rhinitis patients in Egypt so we recommend further comprehensive research.

Some of the limitations of this study consisted of a 1year period, which limit the generalization and comprehensive comparison of the results over the years, so large sample containing different years, with correlation with geographical residence of the patients with common aeroallergens found is needed.

\section{Conclusion}

This study assessed the most common aeroallergenes among allergic rhinitis Egyptian patients. The results showed the significance of mites and pollens allergens and the poly-sensitization pattern among the allergic rhinitis patients in Egypt. This study may be of use to allergist in any diagnostic or therapeutic strategy for the treatment of patients with allergic rhinitis. 


\section{Acknowledgements}

Not applicable.

\section{Authors' contributions}

HE and AA conceived, designed and conducted the study, HE analyzed the data. HE and AA wrote the paper and contributed to manuscript revision. All authors have read and approved the manuscript.

\section{Funding}

No financial support.

\section{Availability of data and materials}

The datasets generated and/or analysed during the current study are not publicly available because it is private data considering our patients, but are available from the corresponding author on reasonable request.

\section{Declarations}

\section{Ethics approval and consent to participate}

It was done in accordance with the ethical standards of the Faculty of Medicine, Ain Shams University Ethical Committee, but reference number is not applicable. Informed verbal and written consent was obtained.

\section{Consent for publication}

Not applicable.

\section{Competing interests}

Prof Ahmed Atef is a co-author of this study. He declares a competing interest for this submission. He hasn't handled this manuscript. The rest of the authors have no conflict of interest to declare.

\section{Author details}

'Department of Internal Medicine, Allergy and Clinical Immunology, Faculty of Medicine, Ain Shams University, Cairo, Egypt. ${ }^{2}$ Department of Otolaryngology, Faculty of Medicine, Cairo University, Cairo, Egypt.

Received: 25 November 2020 Accepted: 11 May 2021

Published online: 31 May 2021

\section{References}

1. Canonica GW, Bousquet J, Mullol J, Scadding GK, Virchow JC (2007) A survey of the burden of allergic rhinitis in Europe. Allergy 62:17-25

2. Mims JW (2014) Epidemiology of allergic rhinitis. Int Forum Allergy Rhinol 4(Suppl2):S18-S20

3. Bousquet PJ, Chinn S, Janson C, Kogevinas M, Burney P, Jarvis D (2007) European Community Respiratory Health Survey I. Geographical variation in the prevalence of positive skin tests to environmental aeroallergens in the European Community Respiratory Health Survey I. Allergy 62(3):301-309. https://doi.org/10.1111/j.1398-9995.2006.01293.x

4. Bousquet PJ, Chinn S, Janson C, Kogevinas M, Burney P, Jarvis D (2007) Geographical variation inthe prevalence of positive skin tests to environmental aeroallergens in the European Community Respiratory Health Survey I. Allergy 62(3):301-309. https://doi.org/10.1111/j.1398-9995.2 006.01293.x

5. Bousquet J, Van Cauwenberge P, Khaltaev N (2001) Aria Workshop Group, World Health Organization: allergic rhinitis and its impact on asthma. J Allergy Clin Immunol 108(5):S147-S334. https://doi.org/10.1067/mai.2001.118891

6. Williams PB, Siegel C, Portnoy J (2001) Efficacy of a single diagnostic test for sensitization to common inhalant allergens. Ann Allergy Asthma Immunol 86(2):196-202. https://doi.org/10.1016/S1081-1206(10)62691-9

7. Bousquet J, Khaltaev N, Cruz AA, Denburg J, Fokkens WJ, Togias A, Zuberbier T, Baena-Cagnani CE, Canonica GW, Van Weel C, Agache I (2008) Allergic rhinitis and its impact on asthma (ARIA) 2008. Allergy 63:8-160. https://doi.org/10.1111/j.1398-9995.2007.01620.x

8. De Amici M, Ciprandi G (2013) The age impact on serum total and allergenspecific IgE. Allergy, Asthma Immunol Res 5(3):170-174. https://doi.org/10.41 68/aair.2013.5.3.170

9. Sakashita M, Hirota T, Harada M, Nakamichi R, Tsunoda T, Osawa Y, Kojima A, Okamoto M, Suzuki D, Kubo S, Imoto Y (2010) Prevalence of allergic rhinitis and sensitization to common aeroallergens in a Japanese population. Int Arch Allergy Immunol 151(3):255-261. https://doi.org/10.11 59/000242363

10. Tungtrongchitr A, Jumpasri J, Sookrung N, Visitsunthorn N, Tantilipikorn P, Piboonpocanan O, Indrawattana N, Tungtrongchitr R, Chaicumpa W (2017) Alteration of-656 (G/T) and-607 (C/A) polymorphisms in interleukin-18 (IL18) gene in house dust mite-sensitive allergic rhinitis patients in Thailand. Genet Mol Res 16(3):gmr16039641. https://doi.org/10.4238/gmr16039641.

11. Ezeamuzie Cl, Thomson MS, Al Ali S, Dowaisan A, Khan M, Hijazi Z (2000) Asthma in the desert: spectrum of the sensitizing aeroallergens. Allergy 55(2):157-162. https://doi.org/10.1034/j.1398-9995.2000.00375.x

12. Biedermann T, Winther L, Till SJ, Panzner P, Knulst A, Valovirta E (2019) Birch pollen allergy in Europe. Allergy 74(7):1237-1248. https://doi.org/10.1111/a 11.13758

13. Mostafa HS, Qotb M, Hussein MA, Hussein A (2019) Allergic rhinitis diagnosis: skin-prick test versus laboratory diagnostic methods. Egypt J Otolaryngol 35(3):262-268. https://doi.org/10.4103/ejo.ejo_8_19

14. Warner AM, Bjbrksten B, Munir AK, Möller C, Schou C, Kjellman NL (1996) Childhood asthma and exposure to indoor allergens: lowmite levels are associated with sensitivity. Pediatr Allergy Immunol 7(2):61-67. https://doi. org/10.1111/j.1399-3038.1996.tb00108.x

15. Salo PM, Yin M, Arbes SJ, Cohn RD, Sever M et al (2005) Dustborne Alternaria alternata antigens in US homes: results from the National Survey of Lead and Allergens in Housing. J Allergy Clin Immunol 5:623-629

16. Hasnain SM, Al-Frayh AR, Subiza JL, Fernández-Caldas E, Casanovas M, Geith T et al (2012) (2012): Sensitization to indigenous pollen and molds and other outdoor and indoor allergens in allergic patients from Saudi Arabia, United Arab Emirates, and Sudan. World Allergy Organ J 5:59-65

17. Wagner N, Rudert M (2019) Sensitivity and specificity of standardised allergen extracts in skin prick test for diagnoses of lgE-mediated respiratory allergies. Clin Transl Allergy 9(1):8. https://doi.org/10.1186/s13601-019-0248-9

\section{Publisher's Note}

Springer Nature remains neutral with regard to jurisdictional claims in published maps and institutional affiliations.

\section{Submit your manuscript to a SpringerOpen ${ }^{\circ}$ journal and benefit from:}

- Convenient online submission

- Rigorous peer review

- Open access: articles freely available online

High visibility within the field

- Retaining the copyright to your article

Submit your next manuscript at $\boldsymbol{\nabla}$ springeropen.com 